Nataša Hirci

Oddelek za prevajalstvo

Filozofska fakulteta Univerze v Ljubljani

natasa.hirci@guest.arnes.si
UDK 81'25:378.147.091.33-027.22

DOI: 10.4312 /vestnik.8.23-40

\title{
KLJUČNA VLOGA PRAKTIČNEGA UPOSABLJANJA V VISOKOŠOLSKEM IZOBRAŽEVANJU: KAJ PREVAJALSKA PRAKSA NUDI BODOČEMU PREVAJALCU?
}

\section{UVOD}

Oddelek za prevajalstvo Filozofske fakultete v Ljubljani je na osnovi prenove študijskih programov po smernicah bolonjske reforme kot del obveznega magistrskega programa Prevajanje/Tolmačenje vpeljal tritedensko praktično usposabljanje v obliki prevajalske prakse. Namen prevajalske prakse je obogatiti in nadgraditi kakovost študija, ponuditi študentom možnost, da že med študijem spoznajo dobre prakse s področja prevajanja in izboljšati zaposljivost diplomantov.

Prevajalska praksa je za večino študentov prvi stik s profesionalnim delovnim okoljem in odlična priložnost za vpogled $\mathrm{v}$ realno prevajalsko situacijo in delo profesionalnega prevajalca. Praktično usposabljanje nadgrajuje tako teoretične kot praktične študijske vsebine in študentom že v času študija ponuja možnost povezovanja s potencialnimi delodajalci in delo z najsodobnejšimi prevajalskimi tehnologijami. Oddelek za prevajalstvo na ta način povezuje akademski svet s širšim družbenim okoljem in usposablja diplomante za potrebe slovenskega in mednarodnega prevajalskega trga dela.

V času opravljanja prevajalske prakse, ki je zasnovana praktično in je usmerjena ciljno, lahko študenti s pomočjo mentorja teoretično in praktično znanje, pridobljeno v času študija, prenesejo v svoje prevajalsko delo. Med prakso spoznajo, katera znanja so pri študiju temeljna, dobijo pa tudi vpogled v realne delovne razmere in pogoje dela ter delovne naloge, ki jih bodo opravljali na področju, za katerega se specializirajo. Spoznajo tudi različne delodajalce, kar je odlično izhodišče za iskanje poklicnih poti. 


\section{2 IZHODIŠČA ZA UVAJANJE NEPEDAGOŠKEGA PRAKTIČNEGA USPOSABLJANJA}

a. Bolonjske smernice

Na Filozofski fakulteti v Ljubljani je obvezna pedagoška praksa že dolga leta stalnica v študijskih programih vseh oddelkov, ki usposabljajo bodoče učitelje (prim. Trškan idr. 2015, Skela idr. 2003). Posebna novost študijskih programov, ki so bili prenovljeni po bolonjskih smernicah, pa je uvajanje tako imenovanega obveznega nepedagoškega praktičnega usposabljanja oziroma nepedagoške prakse.

Izhodiščna predpostavka je, da praktično usposabljanje študentom nudi poglobljen vpogled $\mathrm{v}$ kasnejše praktično delo, omogoča prenos znanja iz izobraževalne ustanove $\mathrm{v}$ delovne organizacije in usposablja diplomante za potrebe trga dela (prim. Govekar Okoliš idr. 2010a, Kristl idr. 2007).

\section{b. $\quad$ Certifikat odličnosti mreže EMT}

Generalni direktorat za prevajanje pri Evropski uniji podeljuje certifikat odličnosti mreže EMT (Evropska mreža magistrskih študijskih programov iz prevajanja) tistim visokošolskim programom za usposabljanje prevajalcev v državah Evropske unije, ki izkazujejo ustrezno kakovost študijskega programa. Na Oddelku za prevajalstvo, ki je član mreže EMT že od leta 2010, že več kot deset let intenzivno vzpostavljamo praktično usposabljanje, ki sledi najnovejšim smernicam tako mreže EMT kot tudi Univerze v Ljubljani.

Za pridobitev magistrske diplome na drugi stopnji visokošolskega študijskega programa Prevajanje/Tolmačenje na Filozofski fakulteti v Ljubljani mora študent poleg drugih študijskih obveznosti opraviti tudi prevajalsko prakso, in sicer kot del programa prvega letnika magistrskega študija. Na Oddelku za prevajalstvo smo kot prvi na Filozofski fakulteti izoblikovali program nepedagoškega praktičnega usposabljanja, ki se navezuje na študijski program, obenem pa omogoča ustrezno pripravo diplomantov za strokovno in vsebinsko pestra in zahtevna delovna mesta na področju prevajanja in tolmačenja.

\subsection{Formalne zahteve}

Oddelek za prevajalstvo je prevajalsko prakso uvajal postopoma, najprej kot neobvezni del študijskega procesa, po prenovi študijskih programov po bolonjskih smernicah pa je s prvo generacijo študentov, vpisanih na magistrska programa Prevajanje/Tolmačenje na drugi stopnji, predmet Prevajalska praksa postal obvezni del magistrskega študijskega programa.

Mreža EMT v svojih smernicah veliko pozornosti namenja predvsem povezavi med izobraževalnimi ustanovami in dejanskim prevajalskim trgom, ter poudarja tesno 
sodelovanje med delodajalci in bodočimi iskalci dela. Vlogo fakultete izpostavlja kot ključno pri zagotavljanju praktičnega usposabljanja in kasnejše zaposljivosti študentov (Smernice EMT 2012: 2-3).

Govekar - Okoliš idr. (2010a: 4-5) navajajo, da je poleg določil v Zakonu o visokem šolstvu za oblikovanje posameznega študijskega programa treba upoštevati tudi Merila za akreditacijo visokošolskih zavodov in študijskih programov (Ur. 1. RS, št. 101/2004) in Merila za kreditno vrednotenje študijskih programov po ECTS (Ur. 1. RS, št. 124/2004). Tako so v 7. členu Meril za akreditacijo visokošolskih zavodov in študijskih programov Sveta Republike Slovenije za visoko šolstvo (Ur. 1. RS, št. 101/2004) opredeljene ključne vsebine študijskih programov; četrta alineja 5. točke navaja, da je v posameznem predmetniku študijskega programa treba določiti delež, način izvedbe in kreditno vrednotenje praktičnega usposabljanja. V Merilih za kreditno vrednotenje študijskih programov po ECTS Sveta RS za visoko šolstvo (Ur. 1. RS, št. 124/2004) mora biti predmet ovrednoten z najmanj tremi kreditnimi točkami (KT), medtem ko je teden dni praktičnega usposabljanja ovrednoten z dvema kreditnima točkama (prim. Govekar - Okoliš idr. 2010a: 5). Tritedenska Prevajalska praksa na Oddelku za prevajalstvo je zato ovrednotena s šestimi kreditnimi točkami.

Univerza v Ljubljani je leta 2007 pripravila Smernice za praktično usposabljanje na Univerzi v Ljubljani (Kristl idr. 2007), tj. univerzitetna navodila, ki opredeljujejo vlogo in namen praktičnega usposabljanja, poleg tega pa navajajo tudi nekaj primerov dobrih praks za organizacijo praktičnega dela prakse pri izbranem delodajalcu.

\subsection{Namen in cilji praktičnega usposabljanja}

Kristl idr. (2007: 7-8) uvrščajo praktično usposabljanje v kategorijo učenja na delovnem mestu, ki je ena od mnogih različnih oblik študijskega procesa, saj praktikantom omogoča, da v dejanskem delovnem okolju preverijo uporabnost teoretičnega in aplikativnega znanja, ki so ga pridobili na fakulteti. Poleg tega praktikanti na delovnem mestu »razvijajo in utrjujejo instrumentalne kompetence«, tj. »metodološke kompetence (sposobnost organiziranja delovnega časa, reševanje realnih problemov, uporaba znanja v praksi), sposobnost ustne in pisne komunikacije in preverjanje tehnične usposobljenosti« (Kristl idr., prav tam). Praktikanti med praktičnim usposabljanjem nadgrajujejo tudi medosebnostne kompetence, na primer »kritičnost, samokritičnost, delo v skupini, etičnost «/.../ in razvijajo sistemske kompetence, kot so: »iniciativnost, kreativnost, avtonomnost pri delu, podjetništvo, sposobnost prilagajanju novostim, skrbi za kvaliteto, raziskovalnih spretnosti in sposobnosti zasnove ter vodenja oz. so-vodenja projektov« (Kristl idr., prav tam).

$\mathrm{Na}$ Oddelku za prevajalstvo smo pri načrtovanju namena in ciljev praktičnega usposabljanja in prevajalske prakse v veliki meri sledili Smernicam za praktično usposabljanje Univerze v Ljubljani (Kristl idr. 2007), ki poudarjajo, da je namen praktičnega usposabljanja predvsem: 
- $\quad$ obogatiti in nadgraditi kakovost študija,

- $\quad$ ponuditi študentom, da že med študijem spoznajo dobre prakse,

- omogočiti prenos strokovnega znanja, veščin in spretnosti, ki jih študent usvoji v študijskem procesu, v neposredno delovno okolje,

- $\quad$ usposobiti bodoči strokovni kader za delo v realnem delovnem okolju,

- povezati akademski svet s širšim družbenim okoljem,

- usposobiti diplomante za potrebe slovenskega in mednarodnega trga dela in omogočiti njihovo kasnejšo zaposljivost.

Zato so cilji prevajalske prakse Oddelka za prevajalstvo usmerjeni predvsem v to, da študent/praktikant na prevajalski praksi v podjetju ali inštituciji, ki se ukvarja s prevajanjem, spozna delovno okolje in organizacijo delovnega procesa, se seznani s poslovanjem delovne organizacije in organiziranjem delovnega procesa ter komunicira $\mathrm{z}$ najrazličnejšimi profili sodelavcev. Poleg tega v času prevajalske prakse spoznava tudi tehnološke specifike podjetja in uporablja najsodobnejše tehnološke pripomočke. V sklopu prevajalske prakse praktikant ves čas dela pod okriljem mentorja, ki ga pri delu spodbuja, vodi in usmerja, obenem pa mu omogoča delo v ekipi profesionalnih prevajalcev. Praktikant tako poglablja znanja z najrazličnejših področij prevajanja kot so na primer gospodarstvo, uradni vladni dokumenti in pravna besedila, poslovne vede, računalništvo in informatika ter medijski in promocijski materiali.

Med prevajalsko prakso praktikant razvija svoje strokovne kompetence, se usposablja za vodenje dokumentacije in projektov, se sooča z različnimi dimenzijami delovnega okolja diplomiranega prevajalca/tolmača, se uči spoštovati moralno-etične vrednote in prevzemati odgovornost tako do dela kot do sodelavcev. Poleg tega mentor praktikanta pouči o pomenu varovanja osebnih in zaupnih podatkov ter varnosti pri delu. Praktikant se nauči dobro upravljati z lastnim časom in ugotovi, katere pridobljene kompetence bi bilo morda treba še poglobiti. Posebej dragoceno je spodbujanje praktikantovega profesionalnega in osebnostnega razvoja ter vzpostavitev mreže poslovnih stikov, kar je nujno za kasnejšo uspešno vključitev na trg dela.

\section{3}

\section{ORGANIZACIJA PREDMETA PREVAJALSKA PRAKSA}

Prevajalska praksa Oddelka za prevajalstvo v Ljubljani je v poskusnem, uvajalnem obdobju trajala dva tedna, a smo jo na željo tako praktikantov kot delodajalcev podaljšali na tri tedne. Po akreditiranem študijskem programu zdaj prevajalska praksa traja 120 ur in je ovrednotena s šestimi kreditnimi točkami (6 KT). Poleg tega Oddelek za prevajalstvo ponuja možnost podaljšanja prevajalske prakse za dodatne tri tedne, kar se priznava kot opravljena obveznost pri zunanjem izbirnem predmetu (dodatnih $6 \mathrm{KT}$ ). Prevajalsko prakso praktikant lahko $\mathrm{v}$ dogovoru $\mathrm{z}$ delodajalcem opravlja med študijskim letom, $\mathrm{v}$ zimskem izpitnem obdobju ali pa $\mathrm{v}$ času poletnih počitnic. 


\subsection{Vloga praktikanta}

S praktičnim usposabljanjem študent prevajalstva pridobiva znanja, veščine in izkušnje, ki mu bodo omogočale kakovostnejše in učinkovitejše delo v prevajalskem sektorju.

\section{Pred prevajalsko prakso}

V sklopu predmeta Prevajalska praksa, ki ga izvajamo v letnem semestru študijskega programa, organiziramo različne dejavnosti, ki pomagajo študentu pri odločitvi, kje naj opravlja prevajalsko prakso (prim. Sliko 1 in Sliko 2). Predmet zajema:

- skupinska srečanja praktikantov in oddelčnega koordinatorja/mentorja na fakulteti, tj. fakultetnega mentorja za prevajalsko prakso,

- individualne konzultacije praktikantov s fakultetnim mentorjem,

- srečanja Praktikant-praktikantu,

- Karierni dan praktikantov in alumnov Oddelka za prevajalstvo.

Skupinska srečanja in individualne konzultacije pri predmetu Prevajalska praksa

Na skupinskih srečanjih fakultetni mentor predstavi namen in cilje prevajalske prakse, različne možnosti opravljanja prakse, delodajalce, s katerimi Oddelek za prevajalstvo sodeluje pri organizaciji prevajalske prakse ter celoten postopek praktičnega usposabljanja: od načrtovanja in izvajanja prevajalske prakse do njene evalvacije (glej Sliko 1), tj. od prijave na prevajalsko prakso do zaključene ocene. Bodočim praktikantom poleg nabora delodajalcev in prijave na prakso fakultetni mentor predstavi tudi obrazce in dokumente, ki jih morajo poznati in jih izpolniti. Individualne konzultacije so namenjene predvsem usmerjanju praktikanta in osebnem svetovanju pri izbiri ustreznega delodajalca.

\section{Srečanja Praktikant-praktikantu}

Srečanja Praktikant-praktikantu so spodbuda študentom drugega letnika magistrskega študija, da v duhu dobrega medštudentskega sodelovanja svoje izkušnje, ki so jih pridobili med opravljanjem obvezne prevajalske prakse, delijo z mlajšimi magistrskimi kolegi in tako bodočim praktikantom morebiti olajšajo odločitev o tem, kje bi lahko uspešno opravljali prevajalsko prakso.

\section{Karierni dan za praktikante in alumne Oddelka za prevajalstvo}

Oddelek za prevajalstvo je prvi oddelek na Filozofski fakulteti, ki je začel z organizacijo t.i. Kariernega dneva za praktikante in alumne Oddelka za prevajalstvo. Ta dogodek je nedvomno izjemnega pomena, saj praktikantu nudi priložnost, da vzpostavi prvi stik s potencialnim delodajalcem, delodajalcem pa omogoči, da osebno spoznajo morebitne 
bodoče sodelavce. Letošnje četrto srečanje (2016) je potekalo pod okriljem Združenja prevajalskih podjetij na Gospodarski zbornici Slovenije.

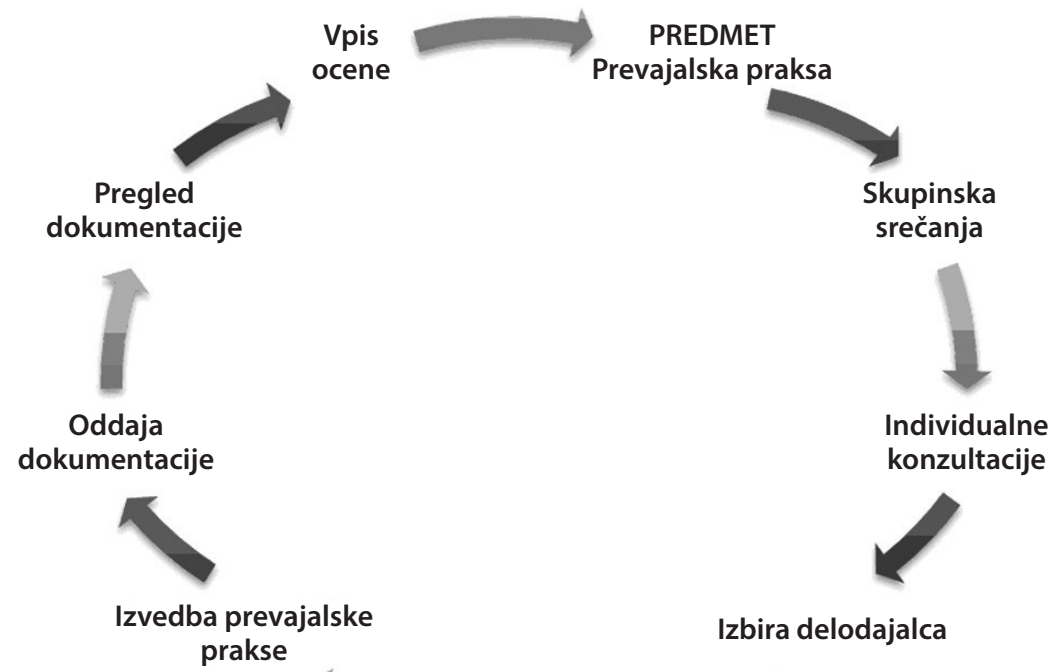

Prijava na prakso

Slika 1: Potek načrtovanja, izvajanja in evalvacije pri predmetu Prevajalska praksa na Oddelku za prevajalstvo

\section{Prijava na prevajalsko prakso}

Študent mora najprej natančno prebrati in slediti Napotkom praktikantom in Navodilom $v 4$. korakih, ki jih je pripravil fakultetni mentor za prevajalsko prakso. Dokumenta podrobno opredeljujeta predpripravo na opravljanje prevajalske prakse, predstavita pa tudi vse obrazce in ostalo obvezno dokumentacijo. Obrazce in navodila o izvajanju prevajalske prakse fakultetni mentor na Oddelku za prevajalstvo objavi v elektronski učilnici. Ko - v dogovoru s fakultetnim mentorjem - študent izbere delovno organizacijo, kjer bo opravljal prevajalsko prakso, se z delodajalcem dogovori o točnem terminu opravljanja prakse. Ko je dogovor sklenjen, študent izpolni obrazec Prijava na prevajalsko prakso in dva izvoda Izjave o praktičnem usposabljanju, ki ju odda fakulteti in delodajalcu, ko pride na delovno mesto. 


\section{Med prevajalsko prakso}

Prvi dan prevajalske prakse organizator prevajalske prakse pri izbranem delodajalcu praktikantu predstavi delovno organizacijo, mu dodeli mentorja, ga spozna z drugimi zaposlenimi in ga seznani z delovanjem delovne organizacije.

Med prevajalsko prakso praktikant tesno sodeluje predvsem z mentorjem, ki mu sproti dodeljuje naloge, za pomoč pa lahko prosi tudi druge člane prevajalske ekipe. Smiselno je, da je praktikant, v kolikor to dopuščajo možnosti znotraj delovne organizacije, čim bolj vključen $v$ celoten proces prevajalskega dela: od naročila prevoda do oddaje prevedenega besedila. Še posebej koristno je, da praktikant prevaja dejanska naročila naročnika prevoda.

Praktikant med opravljanjem prevajalske prakse piše dnevnik dela, v katerem podrobneje predstavi svojo izkušnjo in delovne naloge, opiše jezikovne kombinacije in smeri prevajanja ter besedilne tipe, ki mu jih mentor pripravi za prevod.

\section{Po prevajalski praksi}

Po opravljeni prevajalski praksi praktikant dokonča svoje poročilo z dnevnikom dela, ki ju odda v elektronsko učilnico. V poročilu poroča o tem, kako se je seznanil s celotnim prevajalskim procesom, $\mathrm{tj}$. od naročila do oddaje prevoda, kdo so bili njegovi sodelavci, $\mathrm{s}$ kom in kako je najtesneje sodeloval, s kakšnimi prevajalskimi tehnologijami in postopki se je srečal med opravljanjem prevajalske prakse, kakšno je bilo sodelovanje z mentorjem $\mathrm{v}$ delovni organizaciji in kako uspešno se je vključil $\mathrm{v}$ delovni proces. V poročilu nas zanima tudi, katere veščine in kompetence bi morebiti bilo treba dodatno osvetliti že v času študija, da se bodo diplomanti kasneje lahko čim bolj uspešno vključili na trg dela. Praktikant izpolni tudi obrazec Poročilo o praktičnem izobraževanju in Anketo o opravljanju praktičnega usposabljanja, od mentorja pa pridobi tudi Potrdilo delodajalca o opravljeni prevajalski praksi z zaključno oceno svojega dela. Mentorjeva ocena je številčna (lestvica od 5 do 10), sicer pa mentorje $\mathrm{v}$ delovni organizaciji prosimo, naj dodajo tudi krajšo opisno oceno praktikantovega dela. Temu sledi oddaja dokumentacije in po prebranem poročilu še končna ocena in vpis ocene v študentov elektronski indeks (prim. Sliko 2). S tem je praktikantova obveznost pri predmetu Prevajalska praksa opravljena.

Praktikant med prevajalsko prakso tako dobi priložnost, da dodobra spozna potencialnega delodajalca, kar je zagotovo dobro izhodišče pri iskanju poklicnih poti, obenem pa spoznava tudi svoje dejanske kompetence in se zave, katere veščine so nujne za opravljanje prevajalskega poklica, kar je odlična osnova za uspešno nadaljnjo poklicno pot. Predvsem je treba poudariti, da med prevajalsko prakso praktikant dobi veliko motivacije za nadaljnje delo in si dviga prevajalsko samozavest, kar je zagotovo dodana vrednost celotni prevajalski izkušnji. 

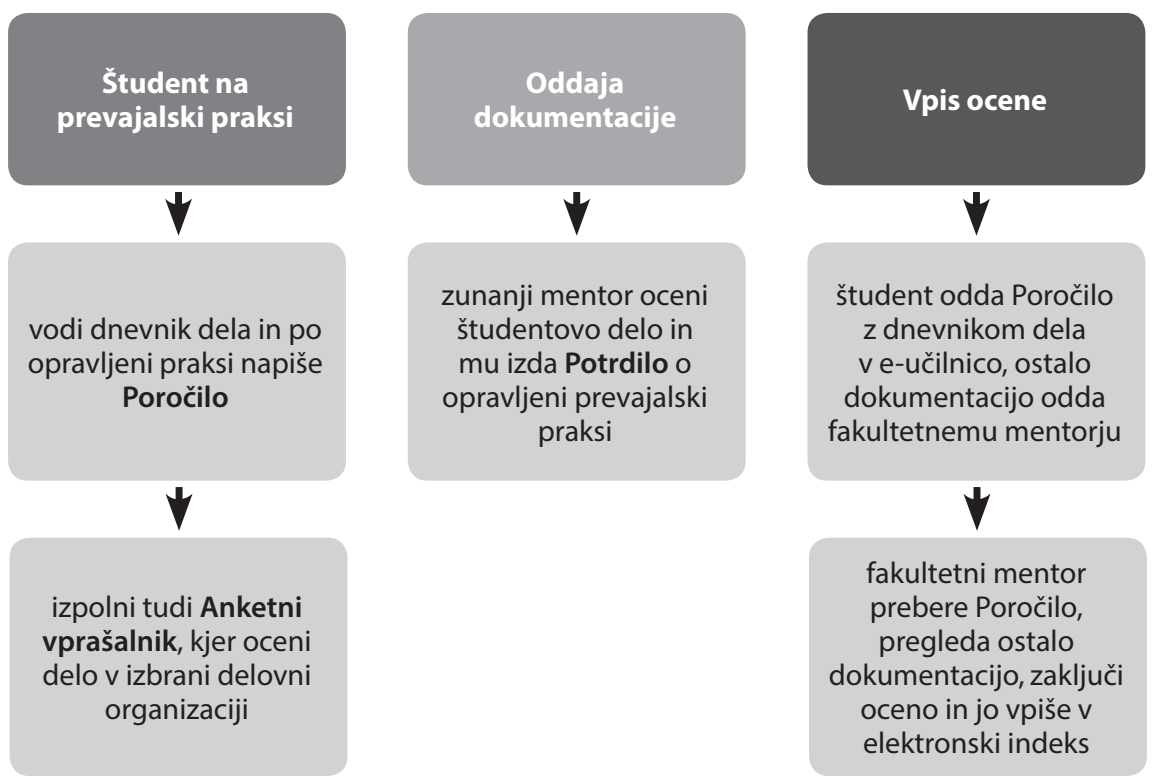

Slika 2: Potek izvedbe Prevajalske prakse

\subsection{Vloga delodajalca}

Delodajalci, s katerimi sodeluje Oddelek za prevajalstvo, prihajajo tako iz gospodarstva kot iz negospodarstva, saj sodelujemo z inštitucijami Evropske unije, z nekaterimi vladnimi inštitucijami, z različnimi prevajalskimi podjetji in agencijami, s sodnimi tolmači, $\mathrm{s}$ turističnimi agencijami, z dvema družbama za podnaslavljanje, z nekaj medijskimi hišami in drugimi podjetji.

Nekateri delodajalci imajo pred opravljanjem prevajalske prakse dodatne zahteve, na primer varnostno preverjanje (predvsem pri vladnih službah), razgovor pred nastopom na delovnem mestu, ki odseva realno situacijo, tj. izvedbo resničnega razgovora pred nastopom službe in testni prevod, ki ga kasneje prav tako dejansko zahteva večina delodajalcev, ki se ukvarjajo s prevajanjem. Občasno mora praktikant opraviti tudi dodatno usposabljanje za delo z različnimi tehnološkimi pripomočki.

V zadnjem desetletju smo sproti odpravili težave, s katerimi smo se soočali na začetku. S podpisom dogovora o sodelovanju je urejena tudi pravno-formalna plat med delodajalcem in fakulteto, vendar pa nekateri segmenti praktičnega usposabljanja še vedno ostajajo odprti. Pereče je predvsem vprašanje vračila potnih stroškov in nadomestila za prehrano, še posebej v privatnem sektorju - to bi vsekakor bilo smiselno rešiti sistemsko. Morda bi veljalo razmisliti tudi o uvedbi simbolne nagrade za opravljeno delo (v javnem sektorju je to že zakonsko opredeljeno), kar bi nedvomno bila dodatna spodbuda praktikantu za nadaljnje sodelovanje $\mathrm{z}$ delodajalcem. 


\subsection{Vloga mentorja}

Mentoriranje je nedvomno izredno pomembno na vseh ravneh človekovega življenja, ne le znotraj izobraževalnih ustanov. Vloga mentorja je zagotovo tudi ena najbolj ključnih v procesu praktičnega usposabljanja, saj lahko močno vpliva na celotno praktično izkušnjo, zato dobro sodelovanje z različnimi mentorji (prim. Sliko 3) nedvomno bistveno prispeva k temu, kako se bo praktikant na praktičnem usposabljanju počutil (prim. Govekar Okoliš idr. 2010a, 2010b, Kristl idr. 2007, Marentič Požarnik 2007, Puklek Levpušček 2007, Trškan idr. 2015, Valenčič Zuljan idr. 2007).

Valenčič Zuljan idr. (2010: 45) povzemajo, da »/t/emelje dobrega medsebojnega odnosa lahko označimo s spoštovanjem, poslušanjem drugega, sprejemanjem drugačnosti in zavedanjem medsebojne odvisnosti v procesu komunikacije. « Govekar - Okoliš idr. (2010b: 14) poudarjajo, da naj bi »potrpežljivost, strpnost, tolerantnost, odprtost, komunikativnost, prijaznost in pozitivna naravnanost, zanesljivost, prilagodljivost in ustvarjalnost« sodile med ključne lastnosti dobrega mentorja.

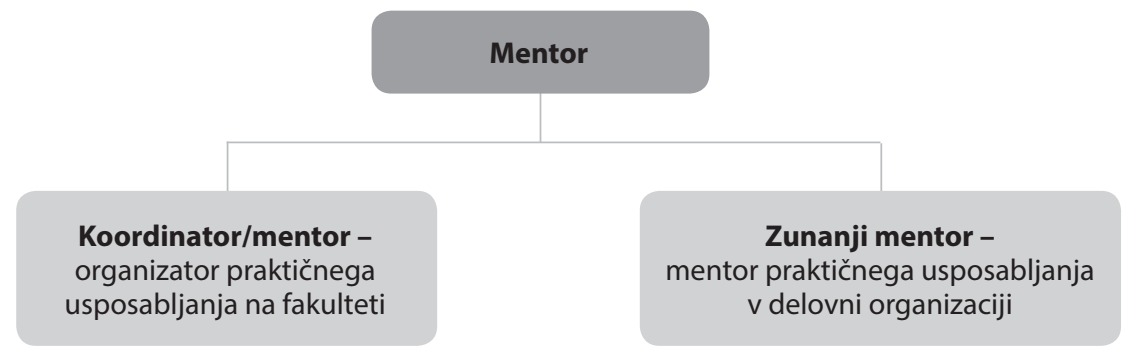

Slika 3: Shema mentoriranja

\subsubsection{Koordinator/mentor na fakulteti}

Uspešen potek praktičnega usposabljanja je zelo odvisen od podpore, ki jo študentom pri izbiri, iskanju in izvajanju praktičnega usposabljanja nudi fakulteta. Na Oddelku za prevajalstvo se tega zelo zavedamo, zato v sklopu predmeta Prevajalska praksa oddelčni fakultetni koordinator/mentor ${ }^{1}$ za prevajalsko prakso organizira skupinska in individualna srečanja.

Zelo je pomembno, da ima študent na vsakem koraku praktičnega usposabljanja pomoč. Tako v obliki spodbude, osebnega svetovanja pri izbiri ustreznega delodajalca in iskanju mest za praktično usposabljanje, kot tudi z ustreznimi napotki in informacijami, ki jih študenti dobivajo še pred opravljanjem praktičnega usposabljanja.

Le z upoštevanjem vseh prej navedenih dejavnikov lahko praktično usposabljanje postane tudi del načrtovanja kasnejše kariere diplomanta. Izmenjava znanj, izkušenj in

1 Vloga koordinatorja/organizatorja in mentorja praktičnega usposabljanja na fakulteti je lahko ločena; na Oddelku za prevajalstvo sta ti dve vlogi dodeljeni le eni osebi, tj. fakultetnemu koordinatorju za prevajalsko prakso. 
informacij med študenti in mentorji, pa tudi med praktikanti, ki so prakso že opravljali, in bodočimi praktikanti zagotovo pomembno prispevajo k uspešnemu izvajanju praktičnega usposabljanja.

\subsubsection{Mentor v delovni organizaciji}

Naloge mentorja $v$ delovni organizaciji, inštituciji, podjetju ali zavodu so: zagotavljanje ustreznih pogojev za delo, dogovarjanje o načinu sodelovanja s praktikantom, uvajanje študenta v delovno okolje, vodenje in usmerjanje študenta, sprotno določanje oblike in vsebine dela, nadziranje študenta pri izdelavi prevodov in ocena študentove uspešnosti. Bistveno poslanstvo mentorja je, da praktikantu ves čas stoji ob strani. Vloga mentorja v delovni organizaciji je, da (povzeto po Kristl idr. 2007):

- spodbuja strokovni razvoj in uči specifične spretnosti,

- uči kritičnega mišljenja, odgovornosti, prilagodljivosti in timskega dela,

- nudi konstruktivne povratne informacije,

- postavlja izzive in dodeljuje odgovornosti,

- spodbuja in daje podporo,

- pomaga vzpostaviti mrežo poslovnih stikov.

Najpomembneje za praktikante prevajalske prakse je zagotovo mentorjevo stalno preverjanje kakovosti prevodov in tesno sodelovanje s praktikantom. Mentor, ki ga vsakemu študentu posebej določa in dodeljuje delovna organizacija, praktikantu pomaga, mu svetuje in mu je za vzor. Zunanji mentorji v veliki večini za svoje delo niso nagrajeni, jim pa fakultetni koordinator po opravljenem mentoriranju izda potrdilo o mentorstvu, ki ga bodo morda v bodoče lahko uveljavljali pri napredovanju na delovnem mestu.

\section{4}

\section{ODZIVI GLAVNIH UDELEŽENCEV}

\subsection{Odzivi praktikantov}

Iz oddanih dnevnikov prevajalske prakse je razvidno, da so praktikanti v večini primerov zelo zadovoljni s celotno organizacijo in izvedbo tega dela študijskih obveznosti. Navajamo nekaj odzivov praktikantov, ki so opravljali prevajalsko prakso tako $\mathrm{v}$ javnem kot v zasebnem sektorju:

»S prakso sem bila zelo zadovoljna. V teh nekaj tednih /../ sem se ogromno naučila, tako $\mathrm{v}$ prevajalskem smislu kot tudi v smislu uporabljanja različnih prevajalskih orodij in nenazadnje tudi $\mathrm{v}$ smislu sodelovanja $\mathrm{z}$ ostalimi kolegi prevajalci in delom v takšnem kolektivu. S svojo mentorico sem odlično sodelovala, vedno mi je bila na voljo, če sem potrebovala pomoč in mi je znala svetovati ter me dobro vodila. Pohvalila bi tudi ostale prevajalce /../, saj so bili 
vedno pripravljeni dati nasvet ali pomagati. Lepo so me sprejeli, kar je še dodatno polepšalo mojo prevajalsko izkušnjo. Na koncu lahko rečem samo to, da upam, da bom še kdaj imela možnost sodelovati z njimi, saj sem doživela res prelepo in zanimivo izkušnjo, ki mi je povečala prevajalsko samozavest in mi dala veliko motivacije za nadaljnje delo.« $\left(\mathrm{D}^{2}\right)$

»Praktično usposabljanje je bila zame izredno pozitivna izkušnja. Zasluga za to gre v veliki meri moji mentorici /../ ter ostalim sodelavkam, od katerih sem izvedela veliko koristnih informacij. Pri pregledovanju prevodov so pokazale izjemno prizadevnost in mi ob morebitnih prevajalskih zagatah vedno prijazno priskočile na pomoč.« (L)

»Praksa je kar prehitro minila. Naučila sem se veliko novih ter uporabnih stvari. Mentor je bil zelo prijazen, dostopen za kakršnokoli pomoč ter mi dal veliko koristnih prevajalskih nasvetov. Tudi ostala prevajalska ekipa me je toplo sprejela in z veseljem odgovarjala na moja vprašanja.« $(\mathrm{H})$

»Po končani praksi lahko z gotovostjo trdim, da je bila izkušnja vsekakor pozitivna in koristna. Vsak dan sem veliko prevajal in se pri tem naučil marsičesa novega, zlasti tehničnih vidikov ter uporabe pripomočkov pri prevajanju. Mentor se je ravno tako polno angažiral, vedno mi je bil na voljo z raznimi koristnimi nasveti in odgovori na moja vprašanja.«(L)

»/../ v tem času izvedel veliko koristnih informacij in pridobil veliko izkušenj, ki jih bom potreboval tako na fakulteti kot pozneje v poklicnem življenju. Zahvala gre predvsem mentorju, ki se je vseskozi zavzemal za to, da bi od prakse odnesel čim več ter da bi po končanem usposabljanju imel jasno sliko o tem, kako novinarsko oziroma prevajalsko delo zgleda v resničnem življenju. Pokazal je veliko prizadevnost, mi stal ob strani, komentiral in popravljal moje prevode ter svoje izkušnje prenašal name. Menim, da sem z opravljanjem prakse zelo veliko pridobil, ne le na področju prevajanja pač pa tudi poklicnega življenja nasploh.« (R)

»Delo v enkratnem timu prevajalcev mi je resnično pomagalo pri napredovanju na področju prevajalskega dela, ki med drugim vključuje tudi delo z različnimi sodobnimi prevajalskimi orodji, ki so nepogrešljiv sestavni del poklica vsakega modernega prevajalca. Poleg tega pa sem bila prvič tudi sama del dejanske prevajalske situacije, ki vključuje prejemanje izvirnega besedila, navodila za prevajanje, oddajanje prevodov, delo v skladu s tehničnimi in jezikovnimi

2 Zaradi zaupnosti podatkov so navedene zgolj inicialke lastnega imena. 
pravili za prevajalce, upoštevanje rokov za oddajo prevodov, upoštevanje potreb in zahtev naročnikov. Sploh bi rada pohvalila odlične sodelavce, ki so mi vedno poskušali odgovoriti na vprašanja in mi po svojih najboljših močeh pomagati pri morebitnih težavah.« (M)

Vendar je treba poudariti, da vsi praktikanti niso enako zadovoljni z opravljanjem prevajalske prakse. Občasno praktikantu ne uspe vzpostaviti ustreznega stika z mentorjem, ki mu je dodeljen $v$ delovni organizaciji, ali pa ne dobi dovolj povratnih informacij niti v času opravljanja prakse niti kasneje, čeprav mu je to obljubljeno. Prav na tem področju je treba izboljšati komunikacijo med delodajalcem in praktikantom, predvsem pa praktikante spodbuditi, da o težavah nemudoma obvestijo oddelčnega mentorja, ki lahko ustrezno posreduje in s tem skuša omiliti negativno doživljanje te študijske obveznosti. V ilustracijo dodajamo tudi nekaj negativnih študentskih mnenj:

》Sproti sem dobival popravljene prevode, s tem da je težava /.../ ponovno ta, da se na nikogar ne moreš obrniti z vprašanjem, zakaj je bilo nekaj popravljeno, kako bi bilo lahko bolje ali čim podobnim.« (B)

»Na prevajalski praksi sem se pogosto počutila nekoliko nezaželeno in nisem imela občutka, da sem v veliko pomoč, še posebej proti koncu prakse. / .../ Prevajanja je bilo malo, razen zadnji teden, vendar žal nisem dobila nobenih napotkov ali navodil, ki bi mi olajšali delo oziroma me usmerili v pravo smer.«(K)

»Žal se moja pričakovanja niso povsem uresničila, ker je bila mentorica skoraj ves čas poteka moja prakse precej zaposlena $\mathrm{z}$ drugimi projekti. Pogrešala sem nekoliko bolj poglobljeno vsebinsko analizo svojih prevodov.« (M)

»Če v podjetju že stremijo k temu, da uporabljajo živ jezik, naj to velja vedno, ne le takrat, ko je to prikladno. Na splošno se z njihovo metodo dela ne strinjam. Obravnavajo te zgolj kot številko, vsa interakcija je neosebna.«(J)

\subsection{Odzivi delodajalcev}

Poleg komentarjev delodajalcev o praktikantih in njihovem delu med prevajalsko prakso so v tem razdelku prikazani tudi rezultati kratke spletne ankete, ki smo jo izvedli spomladi 2016 in jo poslali vsem delodajalcem, s katerimi Oddelek za prevajalstvo trenutno sodeluje pri izvedbi prevajalske prakse. Dobili smo odgovore 10 delodajalcev. Večino odgovorov so prispevali mentorji ali organizatorji prevajalske prakse $\mathrm{v}$ delovni organizaciji.

V delu vprašalnika o praktikantovih lastnostih, ki se delodajalcem zdijo najpomembnejše za uspešno sodelovanje, so vsi anketirani zunanji mentorji kot najpomembnejše 
(100\%) izpostavili predvsem: delovno disciplino, redoljubnost, odgovornost in zanesljivost, odlično jezikovno znanje, ustrezno kulturo govora in pisanja, kakovostno opravljanje dodeljenih nalog, primeren odnos do sodelavcev in strank ter splošno zainteresiranost in vedoželjnost. Nekoliko manj pomembni (80\%) so se jim zdeli: konstruktivno sodelovanje in delo v skupini ter osebna urejenost in splošna kultura, medtem ko so strokovno znanje (50\%) in sposobnost reševanja težavnejših nalog (40\%) ocenili kot manj pomembni lastnosti.

Del vprašalnika je vseboval trditve, s katerimi so se anketiranci lahko strinjali zelo, delno ali pa se s trditvami niso strinjali (prim. Tabelo 1).

Tabela 1: Opažanja zunanjih mentorjev

\begin{tabular}{|l|c|c|c|}
\cline { 2 - 4 } \multicolumn{1}{c|}{} & $\begin{array}{c}\text { zelo se } \\
\text { strinjam }\end{array}$ & $\begin{array}{c}\text { delno se } \\
\text { strinjam }\end{array}$ & $\begin{array}{c}\text { se ne } \\
\text { strinjam }\end{array}$ \\
\hline Pri delu so pokazali primeren odnos do sodelavcev. & 9 & 1 & 0 \\
\hline Ni bilo posebnih težav z delovno disciplino. & 9 & 1 & 0 \\
\hline $\begin{array}{l}\text { Prevajalska praksa je koristen način spoznavanja } \\
\text { potencialnih sodelavcev. }\end{array}$ & 9 & 1 & 0 \\
\hline Študenti so bili zelo zadovoljni z delom pri nas. & 8 & 2 & 0 \\
\hline Študenti so pokazali velik interes za prevajalsko prakso. & 7 & 3 & 0 \\
\hline Študenti so v celoti izpolnili naša pričakovanja. & 2 & 6 & 1 \\
\hline Njihovo delo je bilo zelo koristno za našo organizacijo. & 2 & 7 & 1 \\
\hline
\end{tabular}

Kar 9 od 10 anketiranih zunanjih mentorjev se zelo strinja s tem, da so praktikanti pri delu pokazali primeren odnos do sodelaveev, da med opravljanjem prevajalske prakse ni bilo težav z delovno disciplino ter da je prevajalska praksa koristen način za spoznavanje potencialnih sodelavcev, po en anketiranec pa se s temi trditvami strinja le delno. Prav tako jih 8 od 10 meni, da so bili študenti zelo zadovoljni s prevajalsko prakso pri izbranem delodajalcu (2 se s to trditvijo strinjata delno), medtem ko se 7 od 10 mentorjev zelo strinja tudi s trditvijo, da so študenti pokazali velik interes za prevajalsko prakso (3 delno).

Obenem se 6 od 10 predstavnikov delodajalcev le delno strinja s trditvijo, da so študenti v celoti izpolnili njihova pričakovanja (2 se s tem zelo strinjata, en pa se $\mathrm{s}$ to trditvijo ne strinja). Prav tako se 7 od 10 vprašanih le delno strinja s tem, da je študentsko delo zelo koristno za njihovo organizacijo ( 2 se s tem zelo strinjata, en pa se s to trditvijo ne strinja). Eden od delodajalcev je v svojem komentarju navedel, da so bili na splošno »študenti zelo zainteresirani in večinoma tudi dobri, a kot vedno je tudi tu odvisno od posameznika, koliko se angažira.« Vsi anketirani mentorji so dodali, da so študentom vedno pripravljeni pomagati in da v njihovih delovnih organizacijah načrtujejo izvajanje prevajalske prakse tudi v prihodnje.

Sledi še nekaj drugih komentarjev delodajalcev tako iz gospodarstva kot iz negospodarstva na delo praktikantov med opravljanjem prevajalske prakse: 
»/.../ je v času opravljanja prakse v prevajalski službi MZZ svoje delo opravljal vestno in odgovorno, upošteval je utečene delovne postopke in druga navodila in nam bil v veliko pomoč.« (L)

»Pri delu je uporabljala orodja SDL Trados in WinAlign. Delo je opravila vestno in kakovostno. Ves čas trajanja prakse je bila zelo aktivna in je z velikim navdušenjem sprejemala različne prevajalske izzive. Vsi prevodi so bili zelo dobri, medicinsko in tehnično besedilo pa kaže ustrezno razumevanje vsebine.« (S)

$» / . . /$ je vestno opravila vse svoje naloge. Prevajala je besedila z zelo različnih področij in ser tako spoznala z različnimi slogi in terminologijo. Pri delu je samostojna, prilagodljiva in dobro organizirana. Dobro se znajde v okolju prevajalskih orodij (memoQ, MultiTerm).«(T)

»Študentka / . . / je med prakso uspešno slovenila gradivo, namenjeno objavi v tiskanih in elektronskih medijih (vsebine serij in filmov) ter izkazala odlično jezikovno in tehnično znanje pri podnaslovnem prevajanju.« (M)

»/.../ je /... / v angleščino prevajala novinarska besedila s področja kulture, športa, gospodarstva, politike in zanimivosti, pri čemer je izkazala odlično poznavanje angleščine, relativno hitro je osvojila tudi primeren način strukturiranja zgodb. Pri delu je pokazala veliko mero samostojnosti in samoiniciativnosti.«(E)

»Študentka se je preizkusila v prevajanju zahtevnejših splošnih in pravnih besedil. Delo je opravljala vestno in natančno, pravočasno in z veliko mero entuziazma. Poleg tega tudi obvlada prevajalska orodja in je na splošno iznajdljiva pri svojem delu.«(V)

$» / . . . /$ je pokazala velik interes za prevajanje in terminologijo. Hitro se je seznanila s potekom dela na slovenskem oddelku DGT, s podatkovnimi zbirkami, orodji in aplikacijami IT ter s smernicami za prevajanje na slovenskem oddelku DGT. Opravila je kakovostne prevode več daljših in zahtevnih dokumentov, učinkovito organizirala svoje delo in dobro sodelovala z ostalimi prevajalci.« (N)

»Med prakso pri nas se je /.../ srečala z zapletenimi pravnimi dokumenti, ki jih je prevedla zelo skrbno in zelo dobro. $Z$ njenim delom, odnosom do dela, skrbnostjo in marljivostjo smo zelo zadovoljni in $\mathrm{z}$ veseljem bi tudi v bodoče sodelovali z njo.« $(\mathrm{G})$ 
Trg za prevajalske usluge se nenehno širi. Zaradi sodobnega sloga življenja, novih tehnologij, globalne proizvodnje in marketinga, velikih potreb različnih medijev in članstva Slovenije v Evropski uniji je dela za prevajalce vse več. Vendar se je prevajalsko delo v zadnjih letih precej spremenilo. Prevajalci niso več zgolj posredniki med izvirnikom in ciljnim jezikom, temveč so tudi lektorji, korektorji, celo uredniki, ki preverjajo ustreznost terminologije in besedila ter so vključeni v revizijo prevodov in v procese naročnika. Zaradi uporabe različnih prevajalskih tehnologij se je izrazito spremenilo tudi samo prevajalsko delo, a zavedati bi se morali, da so sodobna prevajalska orodja zgolj pomagala, ki nam lahko olajšajo delo. Četudi še ni povsem jasno, v kolikšni meri se bodo prevajalci in trg prevajalskega dela morali prilagoditi tehnološkemu napredku, je pomembno predvsem to, da smo ljudje tisti, ki lahko vplivamo na kakovost prevoda, kar bi nujno moralo ostati osnovno vodilo ne le pri ponudnikih prevajalskih storitev, ampak tudi pri naročnikih prevodov.

Prevajalska praksa je nedvomno prvi korak k takšnemu ozaveščanju, saj je pomemben del pridobivanja in razvijanja specifičnih kompetenc, ki so usmerjene na večjo zaposljivost diplomantov. Med opravljanjem prevajalske prakse praktikant lahko integrira na fakulteti pridobljeno znanje s prakso, obenem pa taka izkušnja zagotavlja avtentične učne situacije, v katerih se lahko sam preizkusi (prim. Kristl idr. 2007). Poleg tega ima še dodano vrednost, ki je neprecenljiva: študentu nudi vpogled $\mathrm{v}$ realni prevajalski sektor in delo profesionalnega prevajalca znotraj delovne organizacije ter dviga raven študentove prevajalske samozavesti, kar je zagotovo temeljnega pomena za vključevanje na prevajalski trg dela.

Vendar pa je treba praktično usposabljanje oziroma prevajalsko prakso v določenih segmentih še dodatno premisliti. Pri delu z zunanjim mentorjem se je treba posvetiti predvsem osveščanju o nujnosti dajanja sprotnih povratnih informacij, ki so izjemno dragocene za razumevanje celotnega prevajalskega procesa. Poleg tega je nujno rešiti tudi vprašanje vračila potnih stroškov in nadomestila prehrane, kar bi bilo smiselno urediti sistemsko.

Dosedanji odzivi tako praktikantov kot tudi delodajalcev, ki imajo v času prevajalske prakse v sklopu Oddelka za prevajalstvo Filozofske fakultete v Ljubljani možnost spoznati potencial bodočih sodelavcev in delodajalcev, so v veliki večini pozitivni, saj se oboji zavedajo koristnosti takšne izkušnje. Model praktičnega usposabljanja oziroma prevajalske prakse Oddelka za prevajalstvo tako ponuja model dobre prakse tudi v širšem okolju Filozofske fakultete, saj dejansko potrjuje uspešen prenos znanja iz teorije v prakso. 


\section{LITERATURA}

DEVJAK, Tatjana (ur.) (2005) Partnerstvo fakultete in vzgojno-izobraževalnih zavodov: izobraževanje - praksa - raziskovanje. Ljubljana: Pedagoška fakulteta Univerze v Ljubljani.

Direktiva Evropskega parlamenta in Sveta 2005/36/ES (Uradni list Evropske unije, L255/2005).

EMT (European Master in Translation). 20. maj 2016. http://ec.europa.eu/dgs/translation/programmes/emt/key_documents/emt_competences_translators_en.pdf.

GOVEKAR - Okoliš, Monika/Renata KRANJČEC/Urška GRUDEN (2010a) Praktično usposabljanje študentov $v$ delovnih organizacijah in primeri dobrih praks. Ljubljana: Znanstvena založba Filozofske fakultete.

GOVEKAR - Okoliš, Monika/Renata KRANJČEC/Urška GRUDEN (2010b) Izobraževanje mentorjev za praktično usposabljanje študentov po bolonjskih študijskih programih v podjetjih/zavodih. Ljubljana: Znanstvena založba Filozofske fakultete.

KRISTL, Julijana/Eva REPE (ur.) (2007) Smernice za praktično usposabljanje na Univerzi v Ljubljani. Ljubljana: Univerza v Ljubljani.

MACAROL, Jana (2005) Iskanje prakse in zaposlitve, priročnik za študente. Ljubljana: Pedagoški center Ekonomske fakultete.

MARENTIČ POŽARNIK, Barica (2007) Vloga mentorja pri spodbujanju profesionalne rasti študentov prihodnjih učiteljev. C. Peklaj (ur.), Mentorstvo in profesionalna rast učiteljev. Ljubljana: Center za pedagoško izobraževanje Filozofske fakultete, 7-48.

Merila za akreditacijo visokošolskih zavodov in študijskih programov (Uradni list RS, št. 101/2004).

Merila za kreditno vrednotenje študijskih programov po ECTS (Uradni list RS, št. 124/2004).

Oddelek za prevajalstvo-Prevajalska praks.: 20. maj 2016.

http://www.prevajalstvo.net/studentska-praksa.

OPALK, Vesna (2003) Vloga mentorja in podjetja pri strokovnih praksah. Ljubljana: Pedagoški center Ekonomske fakultete.

PUKLEK LEVPUŠČEK, Melita (2007) Kompetence učiteljev - mentorjev študentom. V: C. Peklaj (ur.), Mentorstvo in profesionalna rast učiteljev. Ljubljana: Center za pedagoško izobraževanje Filozofske fakultete, 49-57.

SKELA, Janez/Urška SEŠEK/Mihaela ZAVAŠNIK ARČNIK (2003) Pedagoška praksa. Teaching Practice Pack: gradivo za praktično usposabljanje učiteljev anglěšcine. Ljubljana: Zavod Republike Slovenije za šolstvo.

Smernice EMT (European Master in Translation). 20. maj 2016. http://ec.europa.eu/dgs/ translation/programmes/emt/key_documents/emt_strategy2012_en.pdf.

TRŠKAN, Danijela/Luka KOMIDAR/Luka Horvat (2015) Kazalniki kakovosti pedagoške prakse na Filozofski fakulteti Univerze v Ljubljani. Ljubljana: Znanstvena založba Filozofske fakultete Univerze v Ljubljani. 


\section{VALENČIČ ZULJAN, Milena/Janez VOGRINC/ Cvetka BIZJAK/ Zvonka KRIŠTOF/} Jana KALIN (2007) Izzivi mentorstva: učbenik. Ljubljana: Pedagoška fakulteta. Vprašalnik delodajalcem: https://www.surveymonkey.com/results/SM-6YYS7PVW/. Zakon o pokojninskem in invalidskem zavarovanju (Uradni list RS, št. 104/2005). Zakon o visokem šolstvu (Uradni list RS, št. 119/2006).

Zakon o zdravstvenem varstvu in zdravstvenem zavarovanju (Uradni list RS, št. 72/2006).

\section{POVZETEK}

V prispevku predstavljamo Prevajalsko prakso Oddelka za prevajalstvo Univerze v Ljubljani, ki je zasnovana praktično in usmerjena ciljno. S prenovo študijskih programov po smernicah bolonjske reforme je na Oddelku za prevajalstvo kot obvezni del magistrskega programa Prevajanje/Tolmačenje predvideno praktično usposabljanje v obliki Prevajalske prakse. Prevajalska praksa je za študente odlična priložnost za vpogled v realno prevajalsko situacijo, delodajalci pa tako lahko spoznajo potencialne bodoče sodelavce. Namen Prevajalske prakse je obogatiti in nadgraditi kakovost študija, omogočiti kasnejšo zaposljivost, ponuditi študentom, da že med študijem spoznajo dobre prakse s področja prevajanja in ponuditi možnosti dela z najsodobnejšimi tehnologijami. Študenti dobijo priložnost, da znanje, pridobljeno na fakulteti, prenesejo v svoje prevajalsko delo in obenem pridobivajo znanja, veščine in izkušnje, ki jim bodo kasneje omogočile učinkovitejšo integracijo v prevajalski sektor. V prispevku podrobneje pregledamo specifične pristope k izvajanju takšne študentske prakse, ki so se v zadnjih desetih letih izoblikovali na Oddelku za prevajalstvo in ponujajo model dobre prakse tudi $v$ širšem okviru praktičnega usposabljanja.

Ključne besede: prevajalska praksa, prenos znanja iz teorije v prakso, profesionalno delovno okolje, realna prevajalska situacija, potencialni delodajalci

\section{ABSTRACT}

\section{A key role of practical training in higher education: what can traineeship offer to trainee translators?}

This paper gives an outline of Traineeship at the Department of Translation, University of Ljubljana, designed as a practical, hands-on experience in translation work for students. In the re-design of the study programmes at the Department of Translation in line with the Bologna Reform, compulsory Traineeship was introduced as part of the MA course in Translation/Interpreting, offering students an insight into real-life translation situations while providing employers with an impression of their prospective employees. The main objective of Traineeship is to give an added-value to the MA course, provide job opportunities and offer students a practical experience while working 
with the state-of-the-art translation technologies. The trainees can apply their knowledge obtained at the faculty to real-life translation assignments while gaining new skills and experience which combined contribute to a more efficient integration into the translation market. The paper explores the specific approaches to the implementation of Traineeship at the Department of Translation developed over the last decade, offering a model of good practice to other traineeship organizers.

Key words: translation traineeship, transfer of knowledge from theory to practice, professional work environment, hands-on translation experience, potencial employers 